\title{
Beyond sponsorship - exploring the impact of cooperation between corporations and $\mathrm{NGOs}$
}

\section{Caroline Dale Ditlev-Simonsen (D)}

\section{Introduction}

Sponsorship is a key element of many companies' marketing. At the same time, companies are increasingly concerned about corporate social responsibility (CSR) (Ditlev-Simonsen 2010, Wirl 2014, Scalet and Kelly 2010, Martínez-Ferrero et al. 2016, The Economist 2008a). This paper will illustrate how combining sponsorships with CSR through non-governmental organizations (NGOs) can be a win-win case both for the company and the NGO. Approaches to document the societal effect of such initiatives will also be addressed.

The article will start by presenting the following key concepts: sponsorship, charity, non-governmental organizations (NGO) and corporate social responsibility (CSR). The demand for integrating CSR into business and documenting its effects will be addressed as well. Thereafter, these concepts will be discussed relative to each other. Different models and theories on businessNGO relationships will be presented, as well as the Cone et al. four-principles model for NGO interaction in this study. Integrating two more principles, goal-setting and effect evaluation, into the Cone et al. model is suggested to capture the increased demand on companies to act on and include CSR in day-to-day business.

The extended Cone et al. model will be applied to three business-NGO initiatives (IKEA-WWWF, WalmartAlliance and The Body Shop-ECBAT) to illustrate how the new model can be applied.

\section{Sponsorship and charity}

Sponsorship as a concept has been around for a long time in different versions. A traditional definition of sponsorship is «a cash and/or in-kind fee paid to a property (typically a sports, entertainment, non-profit event or organization) in return for access to the

Correspondence: caroline.d.ditlev-simonsen@bi.no

BI Norwegian Business School, Oslo, Norway exploitable commercial potential associated with that property» (McKelvey and Grady 2008).

Corporate sponsorship is a form of marketing in which a corporation pays for all or some of the costs associated with a project or program. In exchange, the company gets its logo exposed, earning attention and-to some extent-goodwill. The global sponsorship market is large, estimated at more than $\$ 38$ billion in 2007, against $\$ 449$ on advertising (The Economist 2008b).

A typical form of traditional sponsorship is to associate with a sporting event. The Olympic Games in 2014, for example, had 10 key sponsors, including Coca-Cola, Dow, McDonald's, Omega and Visa. The Olympics organization says the games "are one of the most effective international marketing platforms in the world, reaching billions of people in over 200 countries and territories throughout the world" (Olympic.org 2014). Because commercial partnerships account for more than $40 \%$ of the Olympics' revenue, sponsoring companies must agree that sponsorship is effective marketing-even though few studies have documented this effect in economic terms. In addition to making the company name and logo visible, sponsors might enjoy other advantages such as free tickets and exclusivity. During the Beijing 2008 Olympic Games, when Visa was a key sponsor, only Visa cards were accepted. The NFL sponsorship revenue for the 2014 season was $\$ 1.15$ billion (Pro Sports 2015).

Sponsorship is not only about financial support. Sponsoring through products is often an alternative or additional element, such as free Coca-Cola for all participants or free computer rentals from Apple in conjunction with an event.

Of the sponsorship models, sports accounts for the largest share. In the North American market, for example, sports accounts for $69 \%$ of sponsorships. In second place is entertainment, followed by causes, arts, and festivals and fairs (IEG 2013).

There has been a continuous growth in total sponsorship spending. In 2011 total global sponsorship spending 
was estimated to be \$ 48.6 Billion, and in 2014 it was \$ 55.3 billion, proximately an annual growth of four percent (IEG 2015)

Whereas sponsorship is about making the company brand visible, usually associated with sports events, charity is about voluntary giving to those in need, usually from a humanitarian perspective. Corporate charity donations are usually managed by a non-governmental organization (NGO).

\section{Non-governmental organizations (NGOs)}

According to the World Bank, an NGO is "a private organization that pursues activities to relieve suffering, promote the interests of the poor, protect the environment, provide basic social services, or undertake community development" (Malena 1995). According to the Business Dictionary, an NGO is a "private sector, voluntary (and usually non-profit and non-sectarian) organization that contributes to, or participates in, cooperation projects, education, training or other humanitarian, progressive, or watchdog activities."

Previous studies reveal that corporate managers often decide which NGOs to donate to or support (Campbell et al. 1999, Atkinson and Galaskiewicz 1988, Bhattacharya et al. 2008).

When a company donates to a cause through a charity, the cause is usually managed by an NGO. Typical NGOs are Save the Children, WWF, Greenpeace, Amnesty International and the Red Cross. These are large international NGOs, and one of their main sources of income is private or corporate donations. Not all NGOs are as well-known. Most NGOs are small, with unknown brands. There are about 1.5 million NGOs in the United States engaged in a variety of activities (U.S. Department of State 2012). In Russia, there are about 277,000 NGOs (Rodriguez 2008), and in India, about 3.3 million NGOs (Indian Express 2010).

For many companies charity is often perceived as a key element of CSR, and corporate donations to NGOs are a significant source of income for NGOs. Since 2007, for example, overall donations from FTSE 100 companies have increased at a faster rate than pre-tax profits. The median donation by FTSE 100 companies has increased from 1 million pounds in 2007 to 3 million pounds in 2012 (CAF 2014).

\section{Corporate social responsibility (CSR)}

In the last 20 years we have seen a tremendous increase in focus on corporate social responsibility. CSR refers to "the responsibilities of enterprises for their impact on society" (European Commission 2017). Addressing environmental issues, human rights and corruption are key elements of CSR (UN Global Compact 2014). By using CSR in the "right" way, companies can lower risk, reduce cost of capital access, improve customer and employee relationships, and contribute to innovation. Figure 1 documents the increased attention on CSR since 1989 based on media coverage. Companies are more concerned about being perceived as responsible and stakeholder engagement is an important step in this direction is an important step in this direction (Brammer and Millington 2004). Advice through cooperation with NGOs can be a good way to develop a CSR program.

Instead of being a corporate "side activity," CSR is becoming more a part of doing business, especially because of its potential positive effects when done the right way (Carroll and Shabana 2010, The Economist 2009, Simona et al. 2013, Rangan et al. 2015, Petrenko et al. 2016, Cha et al. 2016, McPherson 2012) and different ways to measure the effect is suggested (Lion et al. 2013). Even though it is also argued that studies reporting on positive effect of CSR are biased and overestimate the positive effect of CSR (Rost and Thomas 2015), there are several examples of how doing CSR right can contribute to increased profitability (Khan et al. 2015).

As customers become more concerned about sustainability, they are more likely to choose responsible products (The Economist 2009, Vasilash 2017, Scherer 2012). Having control over a company's responsibility activities can reduce the risk of scandals associated with, for example, uncontrolled emissions corruption, leading to bad media coverage. Also, more responsible products can contribute to a better reputation and branding (Siltaoja 2006). Employees wants to work for responsible companies. Studies show that $80 \%$ of people $13-25$ years old want to work for a company that cares about its impact and contribution to society (Meister 2012). Last but not least, investors are becoming more concerned about the level of responsibility in companies they invest in as part of the due-diligence process. From 2012 to 2014, the "global sustainable investment market has continued to grow both in absolute and relative terms, rising from $\$ 13.3$ trillion 1 at the outset of 2012 to $\$ 21.4$ trillion at the start of 2014 , and from 21.5 to $30.2 \%$ of the professionally managed assets in the regions covered" (GSIA 2015).

The fact that CSR is becoming an integrated part of doing business, and included in companies' long-term strategies, implies that it needs to be evaluated from a business point of view. Business in general can be measured in numerical figures like profit and loss, but the impact of CSR is more complicated to quantify. Even though some activities, such as waste generation and reduction, and changes in $\mathrm{CO} 2$ emissions, can be measured in numbers, it is more difficult to measure the effect of using more environmentally friendly products in the supply line, creating better working conditions in factories, or helping children in developing countries. 


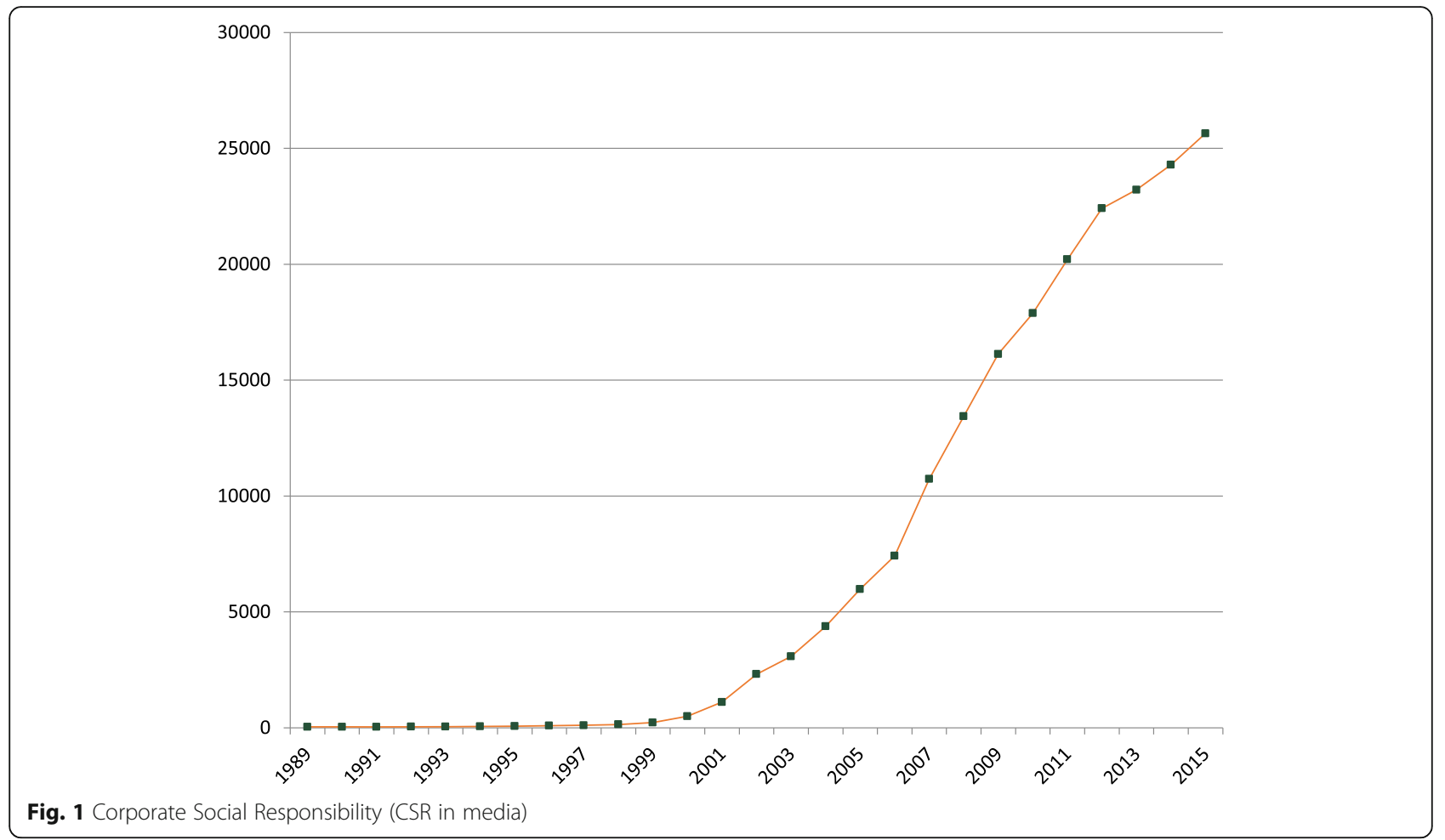

Although measuring the contribution of CSR engagement in dollars and cents is complicated, such activity can still be measured based on its result relative to the goal that has been set. To evaluate the extent a project has fulfilled its mission, however, a goal must be set. Goals that can be accounted for include higher sales of environmentally friendly products; an increase in the number of workers affected by improvements in working conditions, or children passing certain exams; and a reduction in accidents or sick-leave.

Today, however, this type of goal-setting for CSR activities is addressed to a lesser degree, at least explicitly in annual reports. The fact that reports addressing CSR are usually referred to as non-financial reports, when such activities do impact financial results-positively or negatively-is itself a paradox. Given that research shows that the manner in which companies addresses CSR has different impact on corporate financial performance. Whereas investment in material sustainability issues can enhance shareholder value, immaterial sustainability investment may hav little or even negative value implications (Khan et al. 2015).

So far this study has presented four key concepts: sponsorship, charity, non-governmental organizations and corporate social responsibility. The paper has addressed how the typical sponsorship is more profitoriented than charity, and how increased growth in CSR presents a business challenge that can be fulfilled by a new type of sponsorship: cooperation and partnership with NGOs. In the next section, different theoretical perspectives of business and NGO partnership with parallels to sponsorship and charity will be presented. Such partnerships between businesses and NGOs combine sponsorship and charity with CSR. If the partnership is done properly, a company can increase its responsibility and improve its bottom line simultaneously.

\section{Theoretical foundation}

No clear-cut business-NGO partnership theory exists. Academics and the media have frequently addressed the business-NGO relationship. However, few concrete suggestions are provided on how companies should cooperate with NGOs. This study will present three leading approaches to business-NGO partnerships: James Austin's strategic alliance; Porter and Kramer's corporate philanthropy with competitive advantage; and Cone, Feldman and DaSilva's cause-and-effect model. The first two will be used mainly to introduce the topic; the latter is a step-by-step model to guide companies on how to interact with NGOs. The study will evaluate the relevance of the Cone et al. model, and suggest how it can be developed to be in line with today's requirements for CSR engagement. The new model will be applied to assess how three companies-IKEA, Walmart and The Body Shop-collaborate with NGOs. The extent to which these companies report on their collaboration will be discussed.

Austin has developed a concept of three stages of strategic alliances between business and non-profit 
(NGO) partnerships: philanthropic, transactional and integrative (Austin 2004). Key characteristics of the philanthropic relationship are low levels of engagement, few resources and activities involved, and little interaction with low strategic value. In the transaction stage, all these elements of engagement increase. At the integrative stage, engagement is high, with a large set of resources involved in many activities at a high level of interaction. The collaboration is of strategic value to both participants.

The relationship stage that companies and NGOs choose is to a large extent related to purpose and potential. Some companies give to only one cause so they will have an "acceptable" response to the many NGOs contacting them to donate. If the company responds, "Sorry, annually we donate to Save the Children and unfortunately we have no budget beyond that," the NGO usually accepts the refusal. A company selecting the integrative NGO relationship has to be prepared for a time-consuming and demanding program. Developing a human rights training program for all employees around the world with Amnesty International, for example, would be an integrative relationship.

In their article "The Competitive Advantage of Corporate Philanthropy," Michael E. Porter and Mark R. Kramer argue that charity can be associated with economic benefits (Porter and Kramer 2002). Their "A Convergence of Interest" illustrates the variation between pure business and pure philanthropy (Fig. 2). This model also suggests that companies should combine business and philanthropy. The article Creating
Shared Value can be seen as a follow-up of this article, as the authors go a step further and argue for companies taking into account its social and environmental impact in decision-making (Porter and Kramer 2011). Being a responsible company is, according to the authors, to combine profit and positive environmental and social impact, and they provide several examples supporting the argument.

Carol L. Cone, Mark A. Feldman and Alison T. DaSilva represent a Boston-based consulting firm specializing in cause branding and marketing (Cone et al. 2003). In their Harvard Business Review article "Causes and Effects," they present four guiding principles to help corporations with cause branding (Fig. 3). Companies can use this practical four-step model to develop a win-win cooperation approach to NGO interaction. The model combines ideas by Austin, Porter and Kramer about different types of NGO partnerships to create an approach companies can use in their day-to-day operations. It's also a practical tool to evaluate already established cooperation agreements reflected in the cases presented in this paper. Here are the four guiding principles introduced by Cone et al.:

1. Select a cause that is aligned with your corporate goals.

All company stakeholders-customers, employees, suppliers, etc.-can be relevant when choosing a topic or cause.

2. First commit to a cause, then pick your partners. When the cause or topic of cooperation is selected, the search for an appropriate NGO begins. To

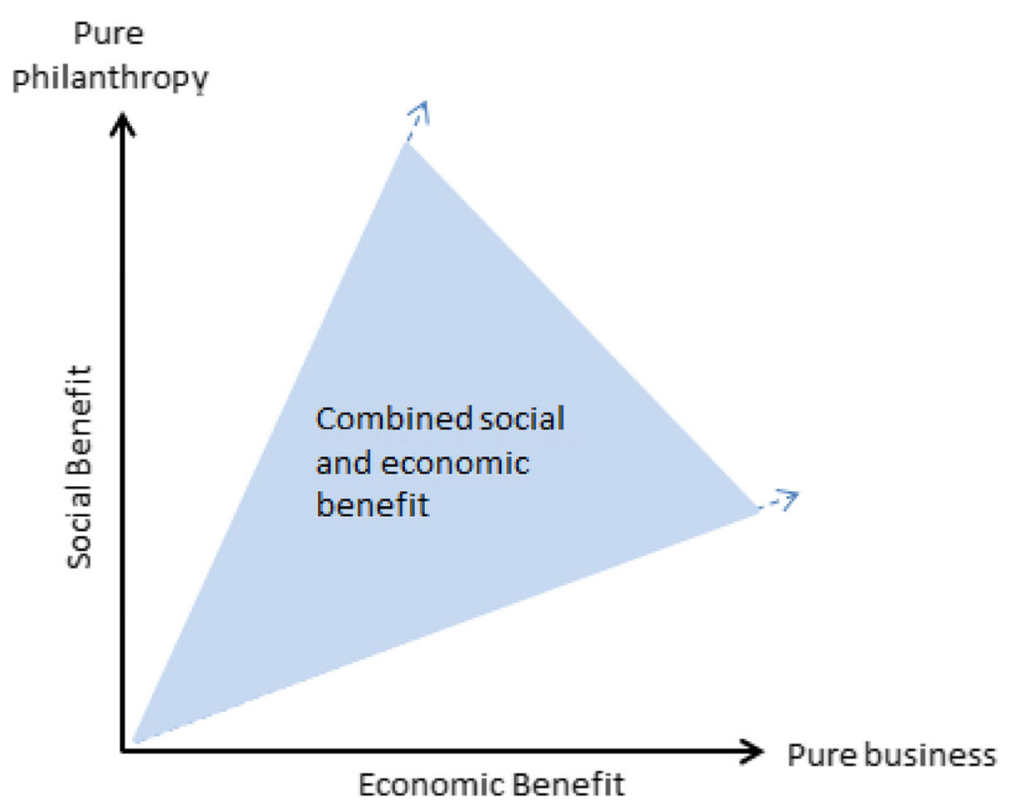

Fig. 2 A Convergence of Interest (Porter and Kramer, 2002) 


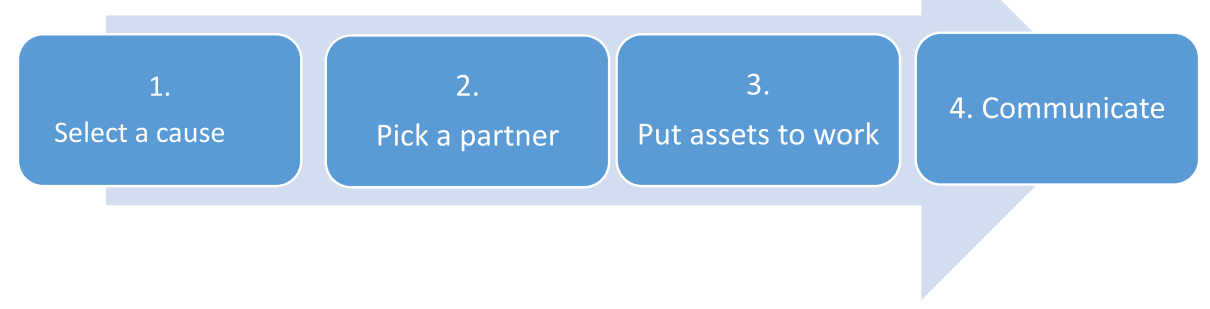

Fig. 3 The Cone et al. model

companies that first pick their cause, the partner might seem obvious, but in reality that's not always the case. Companies often start supporting the NGOs that are the most "pushy" or aggressive, leading to mismatches of companies and NGOs.

3. Put all your assets to work, especially your employees.

Collaboration is not only the responsibility of the company leadership team or information department. All employees should be aware of and understand the choice of NGO. The more a company involves employees, the better. Employees might, for example, provide services, share knowledge or serve as voluntary ambassadors for the cause.

4. Communicate through every possible channel. Making employees aware of the cooperation is a first step. Other stakeholders, such as customers, investors, suppliers and governmental agencies, are potential good ambassadors and should be aware of the collaboration when relevant.

The Cone et al. model is qualitative and descriptive, providing a practical, step-by-step way for companies to pick and start cooperating with an NGO.

However, when it comes to setting goals and evaluating the effect of this cooperation, the model is less concrete. The model does not explicitly assess what is to be achieved and how to measure it.
According to the model, a company can pick the right cause and partner, engage stakeholders and communicate the partnership. However, as addressed earlier in this paper, when CSR is part of doing business, goals have to be set and results evaluated. Because the current model does not require a concrete goal, it is difficult to evaluate the collaboration's effect, whether it was a success, and how it can be improved.

Developing the model a step further by 1) setting concrete goals and 2) effectively evaluating the project, will improve the usefulness of the model. In Fig. 4, this new model is presented.

This new six-step model will be applied to evaluations of NGO cooperation with IKEA, Walmart and The Body Shop. The extent to which these companies report according to the new model will be discussed, providing a test of the new model and how companies can improve their NGO partnership reporting.

\section{Method}

The three cases are convenient samples: large companies with well-known brands that sell to individual customers. Furthermore these companies are well known brands in the retail marked as well as companies with and extremely loyal customer base (Aaker 2011). The companies originated in different countries-Sweden (IKEA), U.S. (Walmart) and U.K. (The Body Shop)—but over time have

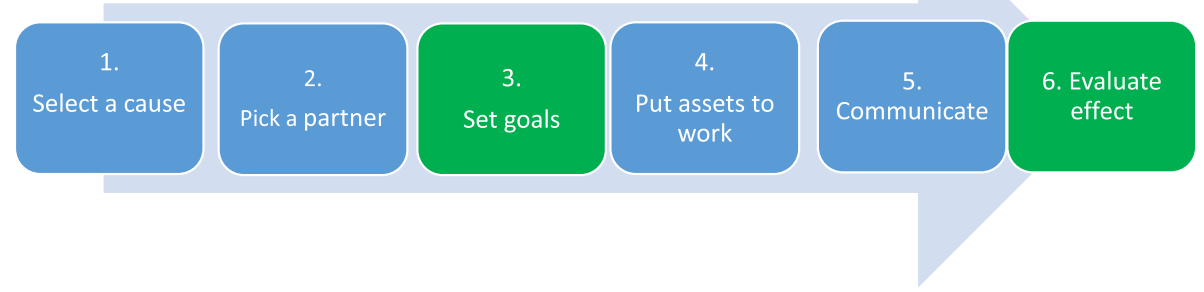

Fig. 4 The revised model of NGO interaction 
become international. Each company cooperates with several NGOs. This paper will study one NGO partnership for each company: WWF (IKEA), Alliance for Bangladesh Worker Safety (Walmart) and End Child Prostitution, Child Pornography and Trafficking of Children for Sexual Purposes (The Body Shop).

Information about the companies' NGO cooperation was retrieved solely from their websites to capture how they present themselves. Company representatives could have been interviewed, but the information would have reflected the interview subjects' personal views of the partnership. Alternatively, one could search the Web to learn how the partnership has been covered in the media, but that approach would be too random to represent the cooperation. Material about the company's NGO collaboration on its own website is the company's official report. What a company chooses to report on about its NGO relationship is itself documentation and contributes to a more objective way of comparing companies. Still, company websites can be of thousand of pages. It might be that this study does not capture all the information available. However, the cases are mainly used to illustrate how to apply the revised model. Therefore the key information provided is acceptable.

The drawback to using the company's website as a sole source is that the study might be missing information that the company has not posted it on its website. However, it is also of interest to investigate what the company actually chooses to focus on and present on its website, so in that case the limitations of what companies put on their websites is itself of interest.

To evaluate business-NGO cooperation, this paper will first describe each company's vision, size, and attitude or policy toward NGO cooperation and partnership, addressing the suggested extension of Cone et al.'s fourprinciple model to a six-principle model. These principles were developed to help managers establish a cause-branding program, and this paper will use the model in retrospect to evaluate the already established NGO cooperation. The principles will be reversed to the following checkpoints:

1. Is the cause chosen in line with the corporate goals? The company's vision, mission and/or purpose will be compared with the cause it has selected.

2. Is the company's choice of NGO partner in line with the cause selected?

3. Has the company set a concrete goal for its collaboration initiative? ${ }^{1}$

4. To what extent has the company put all its assets to work, especially the employees? For instance, does the company mention employees?

5. How does the company communicate its NGO cooperation? The degree to which this is a balanced presentation-not promoting too little, or too much - will be addressed.

6. Is the effect of the project evaluated? ${ }^{2}$

The purpose of this exercise is to illustrate how the model can be applied, and investigate to what extent leading international corporations like IKEA, Walmart and The Body Shop are presenting their relationship with key NGO partners. This research approach can be described as a comparative case study based on multiple (three) cases. Common denominators for selection of cases are leading companies in the retail industry and their association with key NGOs. Applying the extended Cone model as a common framework for evaluating the three companies' NGO interaction is a good tool to identify similarities and differences between the companies. This approach also tests the extended Cone model to evaluate how much the companies have integrated NGO interactions into their business operations, as well as the degree of awareness and openness associated with their NGO collaborations.

This study of IKEA, Walmart and The Body Shop's NGO interactions is on purpose simplified. The data is based on searching the companies' websites for how they present their NGO interaction, and providing a summary. Applying this approach makes it possible to compare the companies as well as test the extended Cone model.

\section{Cases}

IKEA

IKEA's vision is "to create a better everyday life for the many people." Its business idea is "to offer a wide range of well-designed, functional home furnishing products at prices so low that as many people as possible will be able to afford them" (IKEA 2017).

IKEA says it works to "achieve quality at affordable prices for our customers through optimizing our entire value chain, by building long-term supplier relationships, investing in highly automated production and producing large volumes. Our vision also goes beyond home furnishing. We want to create a better everyday for all people impacted by our business."

Total sales for IKEA Group were in 2015 were about 31.9 billion euros. $^{3}$ IKEA has 389 stores in 42 countries, 915 million visits and employs 183,000 workers. ${ }^{4}$

IKEA's policy for NGO interaction is the following: "The IKEA Group co-operates with companies, trade unions, NGOs and organizations to develop and reinforce the impact of our work within the social and environmental fields. From a social perspective IKEA Foundation has partnerships with UNICEF, Save the Children and UNDP. From an environmental perspective the IKEA Group has a partnership with WWF, the global conservation organization." ${ }^{5}$ This study will focus 
on IKEA's cooperation with WWF (World Wide Fund for Nature).

1. Is the cause chosen in line with the corporate goals? IKEA says it wants to create a better everyday for all people impacted by its business. Focusing on a cause related to key products in its value chain, wood and cotton, is in line with the corporate goal.

2. Is the company's choice of NGO partner in line with the cause selected?

"WWF, the global conservation organization, is one of the world's largest and most experienced conservation organizations with a global network in more than 100 countries. WWF's mission is to stop the degradation of the planet's natural environment and to build a future in which humans live in harmony with nature, by conserving the world's biological diversity, ensuring the sustainable use of renewable natural resources and promoting the reduction of pollution and wasteful consumption." WWF is therefore an NGO partner in line with the cause chosen.

3. Has the company set a concrete goal for its collaboration initiative?

(Search: Ikea WWF Partnership goal). On IKEA's website, no concrete goal is described for the effect of the WWF forestry partnership, other than where it will be conducted. For the Better Cotton project, however, several concrete and well-described goals are presented on the website, such as, "The aim is for 2000 farmers in Pakistan to pass through the Farmer Field Schools during the 3-year period."

4. To what extent has the company put all its assets to work, especially employees?

IKEA actively promotes its cooperation with the WWF on its homepage with a separate document that describes the collaboration. The focus has been on suppliers, because they deal with forestry and cotton production. The extent to which employees are aware of this partnership is not addressed.

5. How does the company communicate its NGO cooperation?

IKEA presents its NGO partnership thorough its website and product certification. This is a balanced approach. It is not evident to what extent the company promotes its NGO cooperation in stores and toward its customers.

6. Is the effect of the project evaluated? (search: IKEA WWF partnership result) On IKEA's website, the results of the WWF partnership are described generally without any concrete figures. ${ }^{7}$ The results of the joint cotton partnership projects in India and Pakistan are thoroughly accounted for. Figures for reduced pesticide and water use, as well as increases in gross margins for farmers, are included. ${ }^{8}$

\section{Walmart}

Walmart's purpose and goal is "Saving people money so they can live better" (Walmart 2014).

Fiscal year 2016 revenues were $\$ 482.1$ billion, and the company employs 2.3 million associates worldwide (http://corporate.walmart.com/newsroom/company-facts)

Walmart collaborates with stakeholders for positive change. "Meaningful collaboration with key stakeholders is essential to driving positive and sustainable change in the supply chain. This is why we continue to work with leading NGOs and take an active role in industry coalitions. We work to improve the effectiveness of our own responsible sourcing program and, ultimately, improve the lives of workers in our supply chain."

From Walmart's website under "Partnership," here are some of the NGOs listed: the Alliance for Bangladesh Worker Safety, Coalition of Immokalee Workers, Ethical Trading Initiative and Global Social Compliance Program. This study will focus on Walmart's cooperation with the Alliance for Bangladesh Worker Safety (Alliance), which started in 2013.

1. Is the cause chosen in line with the corporate goals? The Alliance was create to improve worker safety in Bangladeshi garment factories through training, factory assessment, safety, transparency and financial commitments. This cooperation is not directly in line with Walmart's goal, but can be perceived as necessary to avoid accidents like the collapse of the Bangladesh factory Rana Plaza in 2013 that killed 1129 people (DePillis 2015).

2. Is the company's choice of NGO partner in line with the cause selected?

Because the cause is increasing safety and working conditions for employees in Bangladesh, the Alliance is a good partner. However, the Alliance is a relatively small NGO, with 27 member companies. In that sense the Alliance does not hold the same international respect as an NGO like the WWF. As a result, cooperation with the Alliance might not be as credible as other partnerships.

3. Has the company set a concrete goal for its collaboration initiative?

On its website, Walmart writes about its 5-year undertaking to improve safety in garment factories in Bangladesh, but no explicit goals are set. ${ }^{9}$

4. To what extent has the company put all its assets to work, especially employees?

Walmart reports about the good work of the Alliance, but does not describe other "assets" being put to work. 
5. How does the company communicate its NGO cooperation?

On its website Walmart describes the Alliance partnership, reporting, for example, the inspection of 587 factories and presentation of basic fire safety training for more than 1 million workers and managers. Other than this website information, and a link to the Alliance's annual report, no other communication channels are readily available.

6. Is the effect of the project evaluated? (Search: Walmart Alliance for Bangladesh Worker Safety partnership result) On its website, Walmart refers to the Alliance annual report, which provides concrete figures for what the organization has accomplished. It has, for example, trained more than 1.2 million factory employees on basic fire safety, provided wages for more than 6600 workers, and documented that the number of employees who know how to react in case of an emergency has increased from $61 \%$ before training to $88 \%$ after training. ${ }^{10}$

\section{The body shop}

Here are the company's core values: "The Body Shop is a leader in promoting greater corporate transparency, and we have been a force for positive social and environmental change through our campaigns around our five core Values: Support Community Fair Trade, Defend Human Rights, Against Animal Testing, Activate Self-Esteem, and Protect Our Planet" (Body Shop 2014).

Retail sales for 2015 were 1559.6 million euros. The Body Shop is owned by L'Oréal and has more than 3000 stores in more thatn 60 countries. ${ }^{11}$

The company describes its cooperation strategy: "Each of our relationships is unique, providing different benefits for the communities, such as a more stable future, or access to basic essentials like education, clean water and healthcare." The Body Shop Foundation engages in projects related to animal protection, environmental protection and human rights. "Campaigning has been part of The Body Shop from the very beginning. The first was Save the Whale, launched with Greenpeace in 1986, followed by Stop the Burning, which collected almost a million signatures to call for action to save the Brazilian rainforest."

In this paper the focus will be on The Body Shop's cooperation with the NGO ECPAT International and its Stop the Sex Trafficking of Children and Young People campaign.

1. Is the cause chosen in line with the corporate goals? Given that one of The Body Shop's five core values is to defend human rights, stopping sex trafficking of children is in line with its corporate goal.
2. Is the company's choice of NGO partner in line with the cause selected?

End Child Prostitution, Child Pornography and Trafficking of Children for Sexual Purposes (ECPAT) is an NGO with more than 80 local groups in over 70 countries. The NGO partner is in line with the cause selected.

3. Has the company set a concrete goal for its collaboration initiative?

(Search: Body Shop ECPAT partnership goal) A report on ECPAT's website, "Creating change through partnership 2012-ECPAT International and The Body Shop," includes three concrete formulated goals, but not concrete numbers, such as achievements in preventions, legislation and law enforcement.. ${ }^{12}$ This report, however, was created to evaluate the partnership.

4. To what extent has the company put all its assets to work, especially employees?

Given that one of The Body Shop's main strategies in NGO cooperation is campaigning for positive change, employees are automatically involved. The partnership, linked to the company's Soft Hands Kind Heart Hand Cream, is based on campaigning and marches, and employees have had a key role. For example, through a petition for the cause, more than 7 million signatures were collected around the world. In another example, Marianne, a Body Shop employee in Denmark, organized a successful march supporting the campaign. More than 1500 people turned up, which created huge media interest.

5. How does the company communicate its NGO cooperation?

The Body Shop describes its communication channels in reports and on its website. Through campaigns and marches, the company makes engagement visible.

6. Is the effect of the project evaluated? (Search: Body Shop ECPAT partnership result) Concrete numbers about the effect of the partnership are presented on The Body Shop's blog: "The law has changed in 20 countries to help protect and support children and young people"; "65 countries supported the campaign"; etc. ${ }^{13}$ On the ECPAT website, a report measures progress against the organization's three campaign goals from 2009 to 2012, when the campaign ended. The before-andafter figures are presented in illustrative graphs, and in sentences such as, "The data revealed that policies and programs on prevention, legal framework and assistance designed and implemented by the 42 countries analyzed have generally increased since $2009{ }^{\prime 14}$ 


\section{Discussion and conclusions}

This study has illustrated how traditional sponsorship and charity can develop into NGO collaborations, becoming a key element in company CSR. It develops Cone et al.'s guiding principles to include goal-setting and evaluation. The revised model is tested by exploring cooperation by IKEA, Walmart and The Body Shop with their respective NGOs. The article demonstrates how NGO cooperation can have different structures and render different results. Still, the revised model can be useful as a guiding tool.

The cases illustrates how NGO partnership and cooperation represent advanced forms of sponsorship. It contributes to general branding, one of the key elements of traditional sponsoring, while also contributing to brand-building as a responsible company (CSR). This study documents how such a win-win approach can be developed and evaluated.

This paper shows that Cone, Feldman and DaSilva's four guiding principles to develop a cause-branding relationship can also be used to evaluate an existing company-NGO partnership. While traditional sponsorships are evaluated based on financial results, business-NGO relationships include the social impact of a company's support. Compared with traditional sponsoring, cooperating with an NGO can have a much larger impact on both the company and society. Through business-NGO cooperation, companies can reduce risk, increase innovation, and engage employees and other stakeholders, which contributes to improved branding.

Companies generally are not familiar with NGO cooperation. Traditional sponsorship is simple and does not require much engagement from companies beyond financial contributions. Extending a traditional sponsorship to an NGO cooperation related to CSR issues is more demanding, but can have greater impact. Applying the model tested in this paper might facilitate and inspire more companies to cooperate with NGOs.

Given that companies are to a much larger degree expected to report on CSR engagement today than when the Cone et al. guiding principles were developed in 2003, the model also needs to be developed. As CSR becomes part of doing business, it is necessary to evaluate companies' engagement in the field as a business operation. The earlier choice of an NGO for charity and collaboration was to a large extent based on the management team's personal preferences (Galaskiewicz and Colman 2006). Now, however, companies need a more business-related decision process for choosing partners (Lion et al. 2013, Austin and Seitanidi 2012). Along with the business approach to NGO collaboration and CSR, it is natural to set goals and evaluate results. These elements are added to the original Cone model.
The three companies evaluated are leaders in the world and have teams to develop and implement NGO cooperation professionally. Based on the revised Cone model, these three companies are evaluating their NGO collaboration, mainly based on the number of people reached or engaged. Still, few have put forward concrete goals, or compared to what extent they have reached goals. It might well be that all three companies set goals initially, but those were only used internally-as were comparisons between original goals and actual achievements.

Companies and organizations engage in environmental and societal activities with the intention to do something "good." The actual effect of these initiatives, however, is rarely measured from a financial point of view. Because impact investment is growing rapidly (Eurosif 2016), companies might need to take the next step of evaluating the impact of NGO interaction. This is also a good approach for evaluating different NGO partners and activities.

The goals of effect evaluation are based not only on economics, but also on learning. This evaluation can be done simply or in a more complex way. By setting concrete goals and evaluating the results, companies can learn more about their way of collaborating and how to improve it-both for the companies and the NGOs.

Further studies should evaluate other business-NGO partnerships and examine more closely what the different stakeholders in companies and NGOs have accomplished through their relationships. This study suggests an extended model to evaluate effect of business-NGO interaction. What worked well and what can be improved are interesting issues to investigate. Furthermore, the model in this paper was used to evaluate activities which had already taken place, i.e. in retrospect. New studies might use the model both as guidance for developing new NGO collaboration and as an evaluation tool for the collaboration subsequently.

\section{Endnotes}

${ }^{1}$ To answer this questions, a search on "company name" "name of NGO" and "partnership" and "goal" was conducted. Information presented on the company's website was used unless otherwise reported

${ }^{2}$ To answer this questions, a search on "company name" "name of NGO" and "partnership" and "result" was conducted. Information presented on the company's website was used unless otherwise reported

${ }^{3} \mathrm{http} / / /$ www.ikea.com/us/en/about_ikea/newsitem/ 091015_IKEA-solid-sales-growth-fy15

${ }^{4}$ https://highlights.ikea.com/2016/ikea-facts-andfigures

${ }^{5}$ http://www.ikea.com/ms/en_JP/about_ikea/our_responsibility/partnerships/index.html 
${ }^{6}$ http://www.ikea.com/ms/en_SG/about_ikea/our_responsibility/ikea_forest_projects/ikea_and_wwf.html ${ }^{7}$ http://www.ikea.com/ms/en_SG/about_ikea/our_responsibility/ikea_forest_projects/ikea_and_wwf.html. ${ }^{8}$ http://www.wwf.se/ikea/source.php/1648066/

WWF_IKEA_SCI_Report_2015results_20160613.pdf

${ }^{9} \mathrm{http}: / /$ corporate.walmart.com/our-commitment-to-

the-workers-of-bangladesh

${ }^{10} \mathrm{http}: / /$ corporate.walmart.com/our-commitment-to-

the-workers-of-bangladesh

${ }^{11} \mathrm{http}: / / \mathrm{www} \cdot$ loreal-finance.com/eng/brands/the-body-

shophttps://www.thebodyshop.com/en-gb/aboutus

${ }^{12}$ http://www.ecpat.org/wp-content/uploads/2016/04/

Creating\%20Change\%20Throught\%20Partnership_FI-

NAL.pdf page 3

${ }^{13} \mathrm{http}$ ://blog.thebodyshop.com/post/20066216691/20-

countries-commit-to-protect-children-from-sex

${ }^{14} \mathrm{http}$ ///www.ecpat.org/wp-content/uploads/2016/04/

Creating\%20Change\%20Throught\%20Partnership_FI-

NAL.pdf page 19.

\section{Competing Interests}

The authors declare that they have no competing interests.

\section{Publisher's Note}

Springer Nature remains neutral with regard to jurisdictional claims in published maps and institutional affiliations.

Received: 19 August 2016 Accepted: 24 May 2017

Published online: 12 June 2017

\section{References}

Aaker, D. 2011. 'Eight characteristics of successful retail concepts.' In R. c. experience (Ed.). https://www.retailcustomerexperience.com/articles/eightcharacteristics-of-successful-retail-concepts/. Accessed 2 June 2017.

Atkinson, L., \& Galaskiewicz, J. (1988). Stock ownership and company contributions to charity. Administrative Science Quarterly, 33(1), 82.

Austin, J. (2004). Strategic alliances: the power of partnering between nonprofits and businesses. In Faculty seminar series. Boston: Harvard Business School.

Austin, J. E., \& Seitanidi, M. M. (2012). Collaborative Value Creation: A Review of Partnering Between Nonprofits and Businesses. Part2: Partnership Processes and Outcomes. Nonprofit and Voluntary Sector Quarterly, 41(6), 929-86.

Bhattacharya, C. B., Sen, S., \& Korschun, D. (2008). Using corporate social responsibility to win the war for talent. MIT Sloan Management Review, 49215, 37-44.

Body Shop 2014. 'Body Shop.' http://www.thebodyshop.com.hk/en/our_ company.aspx. Accessed 2 June 2017.

Brammer, S., \& Millington, A. (2004). Stakeholder Pressure, Organizational Size, and the Allocation of Departmental Responsible for the Management of Corporate Charitable Giving. Business and Society Review, 43(3), 268-95.

CAF 2014. 'Corporate Giving by the FTSE 100.' In C. C. A. Foundation (Ed.). CAFhttps://www.cafonline.org/docs/default-source/about-us-publications/ corporate_giving_ftse100_august2014.pdf?sfvrsn=9bd0f440_5. Accessed 2 June 2017.

Campbell, L., Gulas, C. S., \& Gruca, T. S. (1999). Corporate giving behavior and decision-maker social consciousness. Journal of Business Ethics, 19(4), 375-83.

Carroll, A. B., \& Shabana, K. M. (2010). The Business Case for Corporate Social Responsibility: A Review of Concepts, Research and Practice. International Journal of Management Reviews, 12(1), 85-105. doi:10.1111/j.1468-2370.2009. 00275.X.

Cha, M.-K., Yi, Y., \& Bagozzi, R. P. (2016). Effects of Customer Participation in Corporate Social Responsibility (CSR) Programs on the CSR-Brand Fit and Brand Loyalty. Cornell Hospitality Quarterly, 57(3), 235-49.
Cone, C. L., Feldman, M. A., \& Dasilva, A. T. (2003). Causes and effects. Harvard Business Review, 81(7), 95-101.

DePillis, L. 2015. Two years ago, 1,129 people died in a Bangladesh factory collapse. The problem still haven't been fixed.' In T. W. Post (Ed.). https:// www.washingtonpost.com/news/wonk/wp/2015/04/23/two-years-ago-1129people-died-in-a-bangladesh-factory-collapse-the-problems-still-havent-beenfixed/?utm_term=.50b06eb9b949. Accessed 2 June 2017.

Ditlev-Simonsen, C. D. (2010). Historical Account of Key Words in Non-Financial Report Titles. Issues in Social and Environmental Accounting, 4(2), 136-48.

European Commission 2017. 'Corporate Social Responsibility (CSR).' https://ec. europa.eu/growth/industry/corporate-social-responsibility_en. Accessed 2 June 2017.

Eurosif 2016. 'European SRI Study 2016.' http://www.eurosif.org/wp-content/ uploads/2016/11/SRI-study-2016-LR-pdf. Accessed 2 June 2017.

Galaskiewicz, J. \& Colman, M. S. 2006. 'Collaboration between Corporations and Nonprofit Organizations.' In W. W. Powell \& R. Steinberg (Eds.) The Non-profit Sector - A Research Handbook. USA.

GSIA 2015. '2014 Global Sustainable Investment Review.' 36. Global Sustainable Investment Alliance.

IEG 2013. '2013 Sponsorship Outlook: Spending Increase Is Double-Edged Sword.' http://www.sponsorship.com/IEGSR/2013/01/07/2013-Sponsorship-OutlookSpending-Increase-Is-Dou.aspx. Accessed 2 June 2017.

IEG 2015. 'Sponsorship spending report - Where the dollars are going and trends for 2015.' (Ed.) 2015 IEG, LLC. In http://www.sponsorship.com/IEGSR/2013/01/ 07/2013-Sponsorship-Outlook-Spending-Increase-Is-Dou.aspx. Accessed 2 June 2017.

IKEA 2017. 'IKEA.' http://www.ikea.com/ms/en_US/this-is-ikea/companyinformation/index.html. Accessed 2 June 2017.

Indian Express 2010. 'India: More NGOs, than school and health centres.' (Ed.) OneWorld South Asia. OneWorld

South Asia. In http://southasia.oneworld.net/news/india-more-ngos-thanschools-and-health-centres\#.WI2-n00zWP. Accessed 2 June 2017. Khan, M., Serafeim G., \& Yoon A. 2015. 'Corporate Sustainability: First Evidence on Materiality.' HBS Working Paper, Number: 15-073. http://hbswk.hbs.edu/item/ corporate-sustainability-first-evidence-on-materiality. Accessed 2 June 2017.

Lion, H., Donovan, J. D., \& Bedggood, R. E. (2013). Environmental Impact Assessment from a Business Perspective: Extending Knowledge and Guiding Business Practice. Journal of Business Ethics, 117, 789-805.

Malena, C. 1995. 'Working with NGOs - A Practical Guide to Operational Collaboration between The World Bank and Non-governmental Organizations.' In W. Bank (Ed.) 7. World Bank.http://documents.worldbank. org/curated/en/814581468739240860/Working-with-NGOs-a-practical-guideto-operational-collaboration-between-the-World-Bank-and-nongovernmentalorganizations. Accessed 2 June 2017.

Martínez-Ferrero, J., Banerjee, S., \& García-Sánchez, I. (2016). Corporate Social Responsibility as a Strategic Shield Against Costs of Earnings Management Practices. Journal of Business Ethics, 133(2), 305-24.

Mckelvey, S., \& Grady, J. (2008). Sponsorship Program Protection Strategies for Special Sport Events: Are Event Organizers Outmaneuvering Ambush Marketers?'. Journal of Sport Management, 22(5), 550-86.

McPherson, S. 2012. 'Why CSR's Future Matters to Your Company.' Harvard Business Review.

Meister, J. 2012. The Future Of Work: Corporate Social Responsibility Attracts Top Talent.' Forbes. Forbes Leadership.http://www.forbes.com/sites/jeannemeister/ 2012/06/07/the-future-of-work-corporate-social-responsiblity-attracts-toptalent/\#36e77a9d3398.Accessed 2 June 2017.

Olympic.org 2014. 'Olympic.org Official website of the Olympic Movement - the Olympic partner (TPP) programme.' http://www.olympic.org/sponsors. Accessed 2 June 2017.

Petrenko, O. V., Aime, F., Ridge, J., \& Hill, A. (2016). Corporate social responsibility or CEO narcissism? CSR motivations and organizational performance. Strategic Management Journal, 37(2), 262-79.

Porter, M. E., \& Kramer, M. R. (2002). The competitive advantage of corporate philanthropy. Harvard Business Review, 80(12), 56-69.

Porter, M. E., \& Kramer, M. R. (2011). Creating shared value. Harvard Business Review, 89(1/2), 62-77.

Pro Sports 2015. 'NFL Sponsorship Revenue Totals \$ 1.15 Billion In 2014 Season.' http://time.com/collection-post/4070299/secret-to-happiness/. Accessed 2 June 2017.

Rangan, K., Chase, L., \& Karim, S. (2015). The truth about CSR. Harvard Business Review, 93(1/2), 40-49. 
Rodriguez, A. 2008. 'Hobbled NGOs wary of Medvedev, Watchdogs are civil lifeline in lawless Russia.' Chicago Tribune.

Rost, K. \& Thomas, E. 2015. 'Reporting Biases in Empirical Management Research The Example of Win-WIn Corporate Social Responsibility.' Business and Society, online. doi:http://journals.sagepub.com/doi/abs/. http://journals. sagepub.com/doi/abs/10.1177/0007650315572858.

Scalet, S., \& Kelly, T. (2010). CSR Rating Agencies: What is Their Global Impact?'. Journal of Business Ethics, 94(1), 69-88.

Scherer, B. (2012). The Right Message: Translating Sustainability Packaging to Consumers. Global Cosmetic Industry, 180(9), 50-52.

Siltaoja, M. (2006). Value Priorities and Combining Core Factors Between CSR and Reputation - A Qualitative Study. Journal of Business Ethics, 68, 91-111. doi:10.1007/s10551-006-9042-4.

Simona, V., Iuliana, C., Luigi, D., \& Mihai, Ț. (2013). Modelling Employee Engagement in Relation to CSR Practices and Employee Satisfaction. Revista Economica, 65(1), 21-37.

The Economist. (2008a). Just good business. Economist, 386(8563), 3-6.

The Economist 2008b. 'Sponsorhip form', The Economist, http://www.economist. com/node/11825607. Accessed 2 June 2017.

The Economist. (2009). The halo effect. The Economist, 415(8944), 56-56.

U.S. Department of State 2012. 'Fact Sheet: Non-Governmental Organizations (NGOs) in the United States.' http://documents.worldbank.org/curated/en/ 814581468739240860/pdf/multi-page.pdf. Accessed 2 June 2017.

UN Global Compact. (2014). 'Overview of the UN Global Compact. https://www. unglobalcompact.org/about. Accessed 2 June 2017.

Vasilash, G. S. (2017). Green Is Good. Automotive Design \& Production, 129(2), 6-6.

Walmart 2014. 'Walmart.' https://www.corporate.walmart.com. Accessed 2 June 2017.

Wirl, F. (2014). Dynamic corporate social responsibility (CSR) strategies in oligopoly. OR Spectrum, 36(1), 229-50.

\section{Submit your manuscript to a SpringerOpen ${ }^{\circ}$ journal and benefit from:}

- Convenient online submission

- Rigorous peer review

- Open access: articles freely available online

- High visibility within the field

- Retaining the copyright to your article

Submit your next manuscript at $\boldsymbol{s p r i n g e r o p e n . c o m ~}$ 